\title{
An Analysis of Students' Hiragana Letters Mastery at Japanese For General Purpose Course of Universitas Negeri Padang
}

\author{
Rita Arni $^{1 *}$ and Prisyanti Suciaty ${ }^{2}$
}

\author{
${ }^{1}$ Universitas Negeri Padang, Padang, Indonesia, $\nabla$ (e-mail) ritaarni@fbs.unp.ac.id \\ ${ }^{2}$ Universitas Negeri Padang, Padang, Indonesia, $\square(e-m a i l)$ prisyanti.aty@fbs.unp.ac.id \\ *Corresponding author. Email: ritaarni@fbs.unp.ac.id
}

\begin{abstract}
This research was done due to the importance of Hiragana letters mastery by beginner Japanese students, especially students of Japanese for General Purpose Course of Universitas Negeri Padang. This is because the Hiragana letters are used in the teaching and learning process. The large number of Hiragana letters makes the students find it difficult to learn. In addition, the Hiragana letters have many similarities in forms. Moreover, the order of writing, intonation, pronunciation (hatsuon), double consonants (sakuon), and long vowels must also be paid attention well. This descriptive quantitative research aims at determining the students' abilities to write and read the Hiragana letters in Japanese for General Purpose Course. It also includes the obstacles they experienced in the teaching and learning process as well as the efforts they made to overcome those difficulties. Based on the test results, it is found that the students' abilities to read the Hiragana letters as obtained from the multiple choice test (59.4) are categorized as sufficient. Meanwhile, their abilities to write as obtained from the essay test (53.9) are categorized as low. It requires efforts from both lecturers and students to improve the students' mastery. This research is designed to provide an overview to lecturers teaching the Japanese for General Purpose Course at Universitas Negeri Padang about the students' abilities. The results are also expected to be taken into consideration for lecturers in designing their learning strategies, teaching materials, and learning evaluation.
\end{abstract}

Keywords: Hiragana, An Analysis of Students' Mastery, Japanese for General Purpose Course

\section{INTRODUCTION}

One of the difficult things in learning Japanese is to understand its letters which is known as Moji. According to Sadewa (2019: 13), the letters in Japanese consist of Hiragana (ひらがな), Katakana (カタカナ), Kanji (漢字), and Romaji ( $\square$ - マ 字). According to Matsumotokou (2016: 2) Hiragana is made in Japan based on the Chinese Kanji, which is formed by remodeling the Kanji then forming a simpler letter. In writing, Hiragana letters are usually written horizontally from left to right. Pamungkas (2013: 7) argues that "Hiragana is used to write words that are native to Japan including places, objects, and other types of words".

At the beginner level, materials about letters are usually given in stages starting with Hiragana, Katakana and Kanji. The first stage that is taught is Hiragana. Hiragana letters have many form similarities, such as letters a (あ) and o (お), ki (き) and sa (さ), nu (ぬ) and me (め), ha (は) and ho (ほ), ta (た) and na (な), wa (わ) and ne (ね) and re (れ). It makes it difficult for the beginner Japanese students, especially students of Japanese for General Purpose, to write, read and memorize them. Apart from their similar shape, Hiragana has its own rules in writing including the form of strokes, writing sequences, intonation, pronunciation (Hatsuon), double consonants (Sakuon), and long vowels.

From the results of preliminary observation done by the authors while teaching the Japanese for General Purpose course, there are still many errors made by students in writing sequences and distinguishing similar letters with different pronunciation. Although Hiragana has been taught from the beginning, it is found that the students still found it difficult to rewrite Hiragana letters during teaching and learning activities in class. From these things, it is necessary to have benchmarks on the level of the students' abilities so that an effective and efficient learning strategy or method can be carried out.

The problems that were examined in this study were Japanese for General Purpose students' abilities to 
write and read Hiragana letters, the obstacles they had in learning Hiragana, and efforts that can be made to overcome the students' difficulties. Meanwhile, the research objective was to determine the level of students' mastery in Hiragana.

Related research has been conducted by Pavina, Dwika (2020), entitled the Ability to Use Hiragana in Goi which Contains Dakuon, Handakuon, Chooon for Students of 2019 at Japanese language education study program of Universitas Negeri Padang. Based on this research, it can be concluded that hiragana mastery of vocabularies with Dakuon, Handakuon, and Chooon in general was categorized as very good with a good average score. There is also a research conducted by Kartini, Afriyani (2019) on the mastery of Hiragana in the form of Sakuon and Youon of XII students of SMAN 7 Padang. Based on this research, it can be concluded that students made mistakes in writing the size of the hiragana つ (tsu) (small) and や (ya), ゆ (yu), よ (yo) (small). In addition, they forgot how to differentiate the pronunciation of the hiragana Sakuon and Youon with different kinds of letters that have similar denominators.

Hiragana is a kind of Japanese characters that has to be mastered by Japanese students in terms of forms and ways of writing. The shape of the Hiragana letters is identical with the curved lines which are different from the Katakana which has straight strokes. Basically, there are 46 letters of Hiragana and they can be combined one another. This combination forms a vocabulary in Japanese. Apart from the basic Hiragana letters, there are also Hiragana Dakuon and Hiragana Youon. Hiragana Dakuon (bold sound) is the basic Hiragana that has been given a Tenten (') above the basic Hiragana. Meanwhile, Hiragana Youon (double consonant) has been added with the letter ya (や) yu (ゆ) yo (よ) (small). The forms and rules of writing Hiragana are as shown in the following picture:

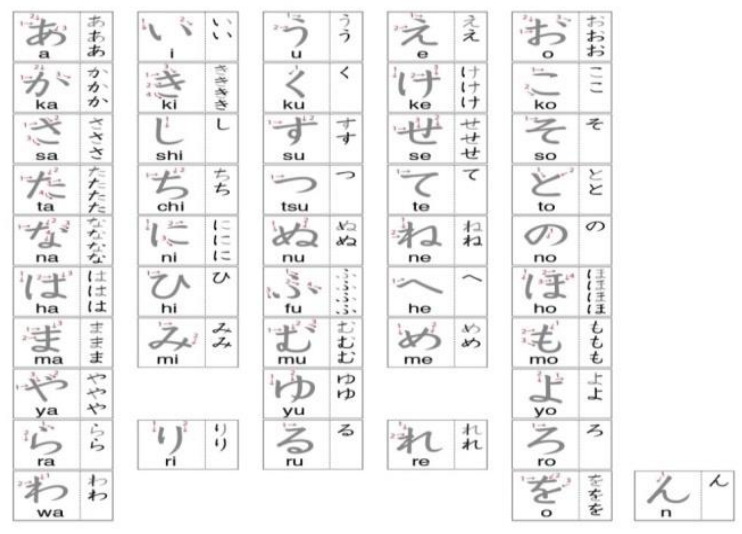

Picture 1. Basic Hiragana Forms and Rules of Writing

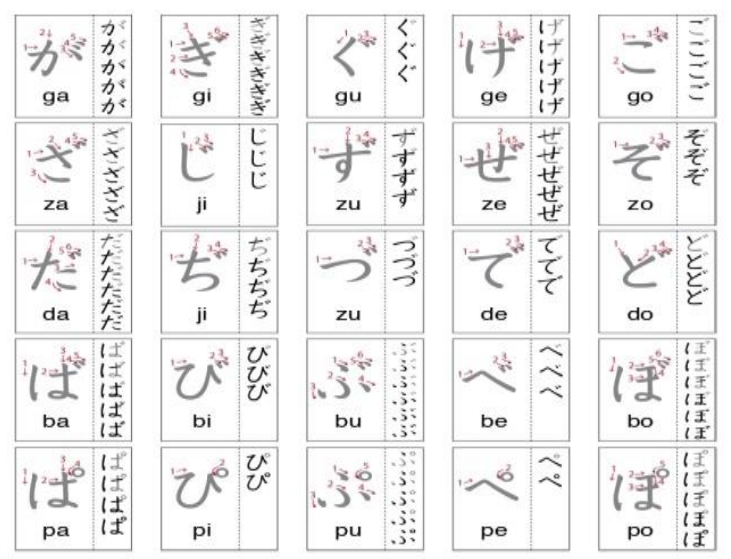

Picture 2. Hiragana Dokuon Forms and Rules of Writing
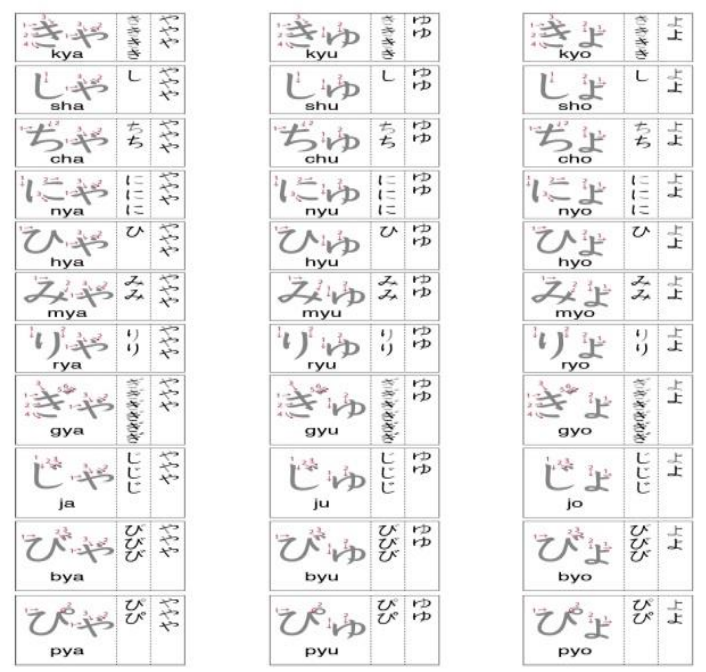

Picture 3. Hiragana Youon Forms and Rules of Writing

Besides having the writing rules, Hiragana also has rules for pronunciation or how to read it. According to Yogyanti (2019: 11) the ways of how to pronounce Hiragana are as follows:

\section{A. Vowel Sounds (Hatsuon)}

There are five vowels in Japanese: [a], [i], [u], [e], [o]. Their writings in Hiragana are あ、い、う、え、 $お$. Besides these five sounds are other sounds in Japanese which consist of consonants and vowels. For example, the sound [ka] consists of a consonant $[\mathrm{k}]$ and a vowel [a], but in practice, the consonant $\mathrm{k}$ cannot be pronounced alone without a vowel. The only consonant that can be pronounced by itself without a vowel is $n$. 


\section{B. Consonant Sounds [n]}

Even though there is only one consonant, this consonant can experience a sound change, if it meets a certain sound. There are three changing forms of it, they are:

a. The consonant $n$ is pronounced [n] when it is followed by $\mathrm{n}, \mathrm{s}, \mathrm{t}$, and $\mathrm{d}$

Examples:

- さんにん Sannin should be pronounced as Sannin ' 3 people'

- せんせい sensei should be pronounced as Sensei ' teacher/lecturer'

- でんとう Dentoo should be pronounced as Dentoo 'lamp'

- はんだん Handan should be pronounced as Handan 'consideration'

b. The consonant $\mathrm{n}$ is pronounced $[\mathrm{m}]$ when it is followed by $\mathrm{p}, \mathrm{b}$ and $\mathrm{m}$.

Examples:

- えんぴつ Enpitsu should be pronounced as Empitsu 'pencil'

- しんぶん Shinbun should be pronounced as Shimbun 'newspaper'

- よんまい Yonmai should be pronounced as Yommai '4 sheets'

c. The consonant $\mathrm{n}$ is pronounced [ng] when it is followed by $\mathrm{k}, \mathrm{g}$ and the consonant $\mathrm{n}$ is at the end of the word

Examples:

- けんがくKengaku should be pronounced as Kenggaku 'field trip'

・だいがくいん Daigakuin should be pronounced as Daigakuing 'postgraduate'

- りんご Ringo should be pronounced as Ringgo 'apple'

\section{Double Consonants (Sakuon)}

There are only four double consonant sounds (Sakuon): pp, ss, kk, and tt. To be able to pronounce a double consonant sound, one Kana letter is needed which is the letter 'つ Tsu' in small size.

Examples:

$\begin{array}{lll}\text { らっぱ } & \text { Rappa } & \text { 'trumpet' } \\ \text { ざっし } & \text { Zasshi } & \text { 'magazine' } \\ \text { きって } & \text { Kitte } & \text { 'postage' }\end{array}$

\section{Consonant Sequence Sounds [Yo'on]}

This sound is formed from a combination of two Kana letters into one sound, by means of all the strings of the letter i, namely all of the letters, $k i$, shi, chi, ni, hi, mi, ri, gi, ji, pi combined with $y a, y u$ and $y o$ and they are small in shape.

\section{E. Long Sounds [Chooon ]}

In Japanese vocabulary there are long sounds and short sounds, when long sounds are pronounced short, the meaning will be changed.

・ おばさん Obasan 'aunty' and おばあさん Obaasan 'grandmother'

・ おじさん Ojisan 'uncle' and おじいさん Ojiisan 'grandfather'

\section{MATERIALS AND METHODS}

The method used in this research was descriptive. Descriptive research is a method that aims at making systematic, factual, and accurate descriptions of the facts and characteristics of a certain population or area (Hidayat, Anwar: 2017). Meanwhile, the research approach was qualitative. According to Sugiyono (2016: 9) a qualitative research method is used to examine the conditions of natural objects where the researcher is the key instrument.

The population of this study was all Japanese for General Purpose course students in January-June 2020. Meanwhile, the samples were 40 students from the population selected using random sampling techniques. The random sampling technique is "a technique that can only be done if the population is considered to have the same character or is close to being homogeneous with a relatively large number" (Sutedi; 2009: 180). The instruments were a multiple-choice test, an essay test and questionnaires. The multiple choice test is used to test the students' Hiragana reading abilities while the essay test is to test their Hiragana writing abilities. For the questionnaire, it was carried out via Google Form where the link was given to students.

The data obtained through the test are grouped according to the categories suggested by Arikunto (2018: 271)

Table 1. Data Categories

\begin{tabular}{|c|c|c|c|c|}
\hline $\begin{array}{c}\text { Score } \\
\text { of 100 }\end{array}$ & $\begin{array}{c}\text { Score } \\
\text { of 10 }\end{array}$ & IKIP & Grade & Category \\
\hline $\begin{array}{c}80- \\
100\end{array}$ & $8,0-10,0$ & $8,1-10$ & A & Excellent \\
\hline $66-79$ & $6,6-7,9$ & $6,6-8,0$ & B & Good \\
\hline $56-65$ & $5,6-6,5$ & $5,6-6,5$ & C & Average \\
\hline $40-55$ & $4,0-5,5$ & $4,1-5,5$ & D & Poor \\
\hline $30-39$ & $3,0-3,9$ & $0-4,0$ & E & Fail \\
\hline
\end{tabular}




\section{RESULTS}

The following tables show the students' mastery

\subsection{Students' Abilities in Writing Hiragana} of writing and pronouncing Hiragana:

Table 2. The scores of the students' hiragana writing mastery

\begin{tabular}{|c|c|c|c|c|c|}
\hline No & Scores & Grade & Category & Frequency & Percentage (\%) \\
\hline 1 & $20-29$ & & Fail & 2 & 5 \\
\hline 2 & $30-39$ & E & Fail & 5 & 12,5 \\
\hline 3 & $40-55$ & D & Poor & 6 & 15 \\
\hline 4 & $56-65$ & C & Average & 12 & 30 \\
\hline 5 & $66-79$ & B & Good & 10 & 25 \\
\hline 6 & $80-100$ & A & Excellent & 5 & 12,5 \\
\hline & Total & & & 40 & 100 \\
\hline
\end{tabular}

From the table, the following descriptions are seen. First, there were 2 students who got an A, which can be classified as excellent. Second, there were 4 students who got a B grade, which is classified as good. Third,

There were 11 students who got a $\mathrm{C}$ grade, which is classified as average. Fourth, there were 17 students who obtained a D grade, which was classified as poor. Fifth, there were 6 students who got an E score, which are classified as fail. Based on the table above, the average score of writing Hiragana in general was 53.92. Thus, it is categorized as poor.

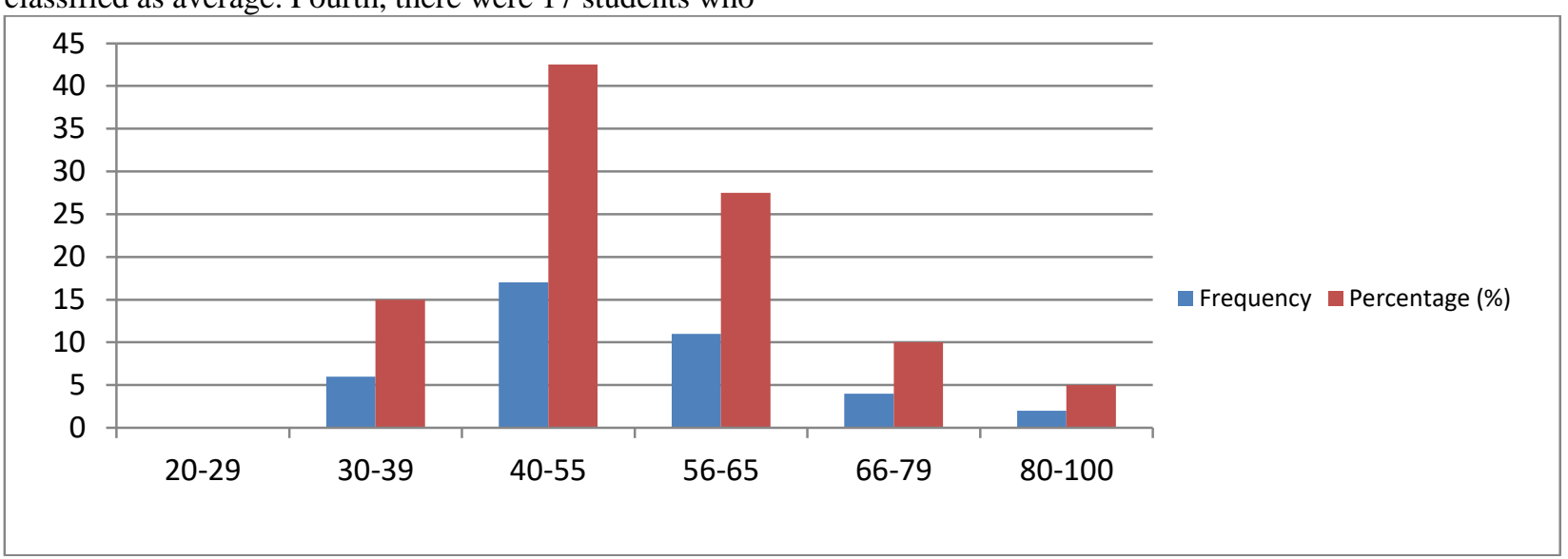

Figure 1.General distribution of students' Hiragana writing mastery

Based on the histogram, the highest percentage is in the 80-100 value range, while the lowest value is in the 20-29 value range. The mastery of the students in writing Hiragana can be grouped into 5 classifications: excellent (5\%), good (10\%), average (27.5\%), poor $(42.5 \%)$, and fail (15\%).

1.2 Students' Mastery in Pronouncing Hiragana

Table 3. The scores of the students' Hiragana pronunciation mastery

\begin{tabular}{|c|c|c|c|c|c|}
\hline No & Scores & Grade & Category & Frequency & Percentage (\%) \\
\hline 1 & $20-29$ & & Fail & 2 & 5 \\
\hline 2 & $30-39$ & E & Fail & 5 & 12,5 \\
\hline 3 & $40-55$ & D & Poor & 6 & 15 \\
\hline 4 & $56-65$ & C & Average & 12 & 30 \\
\hline 5 & $66-79$ & B & Good & 10 & 25 \\
\hline 6 & $80-100$ & A & Excellent & 5 & 12,5 \\
\hline & Total & & & 40 & 100 \\
\hline
\end{tabular}


Based on the table, the following descriptions are obtained. First, there were 5 students who got an A, which is classified as excellent. Second, there were 10 students who got a B grade, which is classified as good. Third, there were 12 students who got a $\mathrm{C}$ grade, which is classified as average. Fourth, there were 6 students who got a D grade, which is classified as poor. Fifth, there were 7 students who got an E score which is classified as fail. The average score of the students was 59.4. Thus, it is categorized as average.

Figure 2. General distribution of students' Hiragana pronunciation mastery

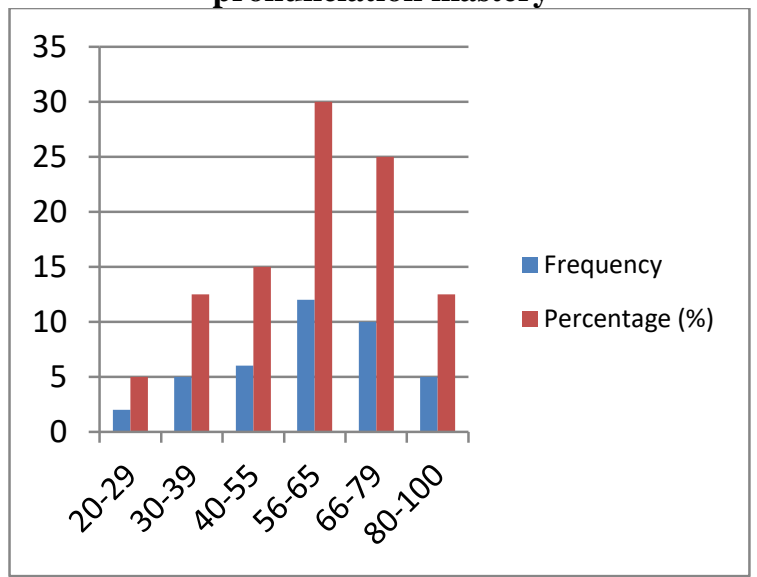

From the histogram, it is seen that the highest percentage is in the $80-100$ value range while the lowest value is in the 20-29 value range. The students' Hiragana pronunciation mastery can be grouped into 5 classifications: excellent $(12.5 \%)$, good $(25 \%)$, average $(30 \%)$, poor $(12.5 \%)$, and fail $5 \%)$.

\section{DISCUSSION}

In general, Hiragana is quite a difficult topic for the students of Japanese for General Purpose course at UNP. It can be analyzed from the overall result of the Hiragana writing and pronunciation test results in an average score $(56.66 \%)$ which is categorized as average. The ability to write Hiragana obtained from the essay choice test was $(53.92 \%)$ which is categorized as poor. Meanwhile, the ability to pronounce Hiragana letters obtained from the multiple choice test $(59.4 \%)$ was average. There are still students' errors in writing Hiragana such as in the shape and sequence of writing Hiragana. Meanwhile, in terms of pronunciation, there are still errors in determining the similar Hiragana letter form and identifying how to pronounce Hiragana letters. Errors in pronouncing and identifying Hiragana letters will cause a mismatch of meaning and will also lead to inappropriate interpretation

\section{CONCLUSION}

Based on the tests that had been carried out, it can be concluded that the mastery of the students' Hiragana letters is categorized as average. The problems faced by the students in mastering Hiragana letters are in the form and order of writing. The error is caused by the large number of letters that must be mastered. Each letter has different writing rules or Kakijun and pronouncing methods according to the rules in Japanese, making it difficult for students to memorize.

Hiragana letters are a benchmark in learning Japanese. Therefore, it is hoped that there will be an appropriate learning method or media to assist students in improving their mastery of writing and pronouncing Hiragana. In addition, the Japanese for General Purpose class is a large class with an average number of 50 students per class. Thus, it is hoped that in the future, applications for learning Hiragana can be created and used.

\section{REFERENCES}

[1] Arikunto, Suharsimi. (2018). Dasar-Dasar Evaluasi Pendidikan. Jakarta : Bumi Aksara.

[2] Dahidi, Ahmad dan Sudjianto.( 2012). Pengantar Linguistik Bahasa Jepang. Jakarta: Kesaint Blanc.

[3] Hidayat, Anwar. (2017). Metode Penelitian: Pengertian, Tujuan, Jenis [ Online]. Tersedia : https://www.statistikian.com/2017/02/metodepenelitian-metodologi-penelitian.html diakses pada tanggal 27 februari 2020

[4] https://www.nhk.or.jp/lesson/english/syllabary/hir agana english.pdf diakses pada tanggal 8 Maret 2020

[5] Kartini, Afriyani. (2019) Penguasaan Hiragana Bentuk Sokuon dan Yoon Pada Siswa Kelas XII SMAN 7 Padang. Dalam Jurnal omiyage Vol 3 No.1, 10 Halaman. Tersedia: http://omiyage.ppj.unp.ac.id/index.php/omiyage/in dex [25 Februari 2020]

[6] Matsumoto. (2016). The Japan Foundation Teaching Japanese Series 3 "Teaching Characters And Vocabulary. Hitsuji : Shobou

[7] Pamungkas. A. Setiawan. 2013. Belajar bahasa Jepang dari nol. Yogyakarta:Buku Pintar

[8] Pavina, Dwika. (2020). Penguasaan Hiragana Pada Goi Yang Mengandung Dakuon, Handakuon Dan Choo On Mahasiswa Tahun Masuk 2019 Program Studi Pendidikan Bahasa Jepang Universitas Negeri Padang. Dalam : Jurnal of Japanese Language Omiyage vol 3 (1), 8 halaman. Tersedia: http://omiyage.ppj.unp.ac.id/index.php/omiyage/ar ticle/view/164 [25 Februari 2020] 
[9] Sadewa, Yoel. (2019). Bahasa Jepang Yang Mudah Yasashi Nihongo. Yogyakarta: Pustaka Widyatama

[10] Sugiono. (2012). Metode Penelitian Kuantitatif Kualitatif dan $R \& D$. Bandung : Alfabeta.

[11] Sutedi, Dedi. (2011). Penelitian Pendidikan Bahasa Jepang. Bandung: UPI Press Dengan Humaniora Utama Press
[12] ........... (2019). Evaluasi Hasil Belajar Bahasa Jepang (Teori Dan Praktek). Bandung : UPI Press Dengan Humaniora Utama Press

[13] Yogyanti dkk. (2019). Cara Mudah Belajar Bahasa Jepang : Yogjakarta : Bhafana. 